\title{
Effect of sex on carcass characteristics and correlation of body weight and blood components in Japanese quails
}

\author{
A. S. Kosshak ${ }^{*}$, N. I. Dim*, O. M. Momoh* and D. Gambo* \\ *Department of Animal Breeding and Physiology, College of Animal Science, University of Agriculture, \\ Makurdi, Benue State, Nigeria.
}

\begin{abstract}
Carcass characteristics and body weights are major determinants of profitability and sustainability of any animal enterprise. Blood as a component of an animal's biological system plays a vital role in accessing the health and productive status of an animal. This study was undertaken on Japanese quails to evaluate the body weight, carcass characteristics and blood constituents at six weeks. The results obtained showed that mean body weight is $133.63 \pm 0.96$ and sex has a significant $(P<0.05)$ effect on body weight favouring females over males. Carcass characteristics is significantly $(P<0.05)$ influenced by sex while blood constituents are significantly $(P<0.05)$ different for haemoglobin $(H b)$, red blood cell count $(R B C)$ and mean corpuscular haemoglobin concentration (MCHC). $\mathrm{Hb}$ and $\mathrm{MCHC}$ revealed a positive, moderate and significant phenotypic correlation while the genetic correlation for $\mathrm{Hb}, M C H C, \mathrm{RBC}$ and packed cell volume (PCV) showed a positive, high in magnitude and highly significant $(P<0.01)$ correlation. It was concluded that this high correlation estimates can be exploited in planning breeding programme for Japanese quails.
\end{abstract}

Key words: Body weight, Blood, Correlation, Carcass, Japanese quails.

\section{Introduction}

The increasing human population puts great pressure on arable land, water and biological resources to provide adequate supply of food while maintaining the integrity of the ecosystem (Kendall and Pimentel, 1994). Low animal protein intake has been identified as the principal cause of malnourishment in many developing countries of Africa and Asia, thus negatively impacting on the physical and health conditions of their people (Olomu, 1995). Animal protein consumption is very essential for meeting the protein requirement of man. This could be supplied by livestock such as cattle, sheep, goat, rabbits, fish and poultry (Onu et al. 2011).

Poultry production has been identified as one major means of solving the problem of low animal protein intake. Poultry can be managed easily with little technical knowledge. It has been reported that eggs and poultry meat rank with cow's milk as the most economically produced animal protein (Awobajo et al. 2007). The term poultry refers to all domesticated birds kept for egg or meat production and includes chickens, turkeys, ducks, geese, ostriches, quails etc (Awobajo et al. 2007).

The Japanese quail (Coturnix coturnix japonica) is the smallest avian species farmed for egg and meat production and it has assumed worldwide importance as a laboratory animal (Baumgartner, 1993; Minville, 2004). The Japanese quail has several advantages which largely have endeared it to be used for biological and genetic studies. These advantages include small body size which makes them easy to handle. A large number of birds can be kept in a limited space; and depending on the day length, some females start laying at thirty five (35) days of age and in full production by fifty (50) days. They also have short generation interval which confers the ability to produce three to four generations per year (Kul and Seker, 2004).

The Japanese quail is bred for egg and meat production (Vali, 2008). In order to establish a breeding programme, it is essential to estimate genetic parameters which will be used for improving the traits of economic importance. The scale of the genetic parameters would show the amount of improvement by selection (Vali et al. 2005; Vali et al. 2006). In addition, if there is a genetic correlation between characters under selection, the overall response will change according to the heritability of the traits examined and the strength and sign of the genetic correlation among them (Jensen et al. 2003). The objective of this study therefore, is to evaluate body weight, carcass yield and blood components of Japanese quails and correlation at six weeks.

\section{Materials and Methods}

This study was carried out in the Poultry section of the Animal Farm of College of Education, Gindiri, Mangu local government area of Plateau state. The design is a nested design where a random sample of males (called sires) is each mated to a unique set of randomly chosen females (called dams) and their offspring are raised and the phenotypic traits of interest measured. A total of 50 four weeks old Japanese quails (consisting of 35 females and 15 males) were purchased from Dhenab Poultry Breeders in Bukuru, Plateau State. These birds served as the foundation stock and were a mixed population of random bred quails. The birds were raised on 
deep litter for the next one week. The birds were fed diet containing $20.5 \% \mathrm{CP}, 2922 \mathrm{Kcal} / \mathrm{Kg}$ ME between the $4^{\text {th }}$ and the $6^{\text {th }}$ week and with layers' diet containing $17 \% \mathrm{CP}, 2859 \mathrm{Kcal} / \mathrm{Kg} \mathrm{ME}$ after the $6^{\text {th }}$ week.

At the end of the fifth week, thirty foundation stock females were randomly selected and placed in ten breeding pens. A mating ratio of 1:3 (i.e. 1 cock to 3 hens) was applied. Each breeding cage had a dimension of $47 \mathrm{~cm}$ (length) X $40 \mathrm{~cm}$ (width) $X 36 \mathrm{~cm}$ (height). All birds were housed in the same room in order that temperature, humidity, light intensity and other variables would be as similar as possible. The cocks mated randomly with the hens. Fertile eggs for hatching were not collected until after nine weeks of age.

The hatching eggs were collected twice a day and accumulated for six days. The collected eggs were held in crates under room temperature with good ventilation. Hatching eggs were given sire identification number. After the six days of collection, the eggs were set in an automated incubator for incubation and hatching at Dhenab Poultry Breeders' hatchery adjacent the Fire Service Station in Bukuru, Plateau State. A total of one hundred and twenty two (122) eggs were collected and seventy two (72) of the eggs hatched. On hatching, all chicks were individually weighed with a digital scale and given individual and sire identities using different colours of oil paints at specific areas of the body for ease of identification.

They were then immediately transferred to the brooding room. No vaccination was administered. The chicks were, however given Stress-ease ${ }^{R}$ and Pantacox ${ }^{R}$ as anti-stress and coccidiostat, respectively. At the end of three weeks of brooding, the chicks were moved to the rearing pen (measuring $2 \mathrm{~m} \times 1.5 \mathrm{~m} \mathrm{x} 1 \mathrm{~m}$ ) and reared together to six weeks on deep litter. Feed and water were provided ad libitum throughout the brooding and rearing periods. The birds were fed with starter diet containing $25 \% \mathrm{CP}, 3022 / \mathrm{Kg}$ ME for the first three weeks and then grower diet containing $20.5 \% \mathrm{CP}, 2922 \mathrm{Kcal} / \mathrm{Kg}$ ME between the $4^{\text {th }}$ and the $6^{\text {th }}$ week.

\section{Traits measured}

Body weight (BD) grams

Live body weight of the birds at 6-weeks was individually recorded using a sensitive digital electronic.

\section{Carcass traits}

At the end of the sixth week, all the quails were starved overnight (for 12 hours), but given enough water. The quails were individually weighed and slaughtered by cutting the jugular vein. Blood from each quail were collected for haematological analysis according to the procedure of Oyewale (1992) as described by Tuleun et al. (2013). The birds are then properly bled (about 4 minutes) and feathers removed manually after dipping in hot water for about two minutes. The carcasses were then manually eviscerated. Wings, breast meat, back, thigh and calculations of dressed percentage were obtained according to procedure and formulae of Alkan et al. (2010).

Dressed \% (DP) $=$ Carcass yield $\quad$ x 100

Live weight

Carcass weight $=$ Live weight $-($ feather weight + head + leg $)$

Carcass yield $=$ Carcass weight - offals

\section{Blood analysis}

Blood samples collected from the quails were immediately taken to Nissi Dominus Medical laboratory, Mangu, Plateau State for haematological analysis for packed cell volume (PCV), haemoglobin concentration $(\mathrm{Hb})$, and total red blood cell (RBC) count. Mean corpuscular haemoglobin (MCH), mean corpuscular volume (MCV) and mean corpuscular haemoglobin concentration (MCHC) were obtained by calculation according to standard formulae (Jain, 1986)

\section{Statistical analysis}

Data were subjected to mixed model analysis of variance to test sex effect for body weight, carcass characteristics, growth rate and blood constituents, using the General Linear Model (GLM) procedure of IBM SPSS Version 20, (SPSS, 2011) according to the following model:

$\mathrm{Yij}=\mu+\mathrm{Si}+\mathrm{eij}$

Where yij=Single observation.

$\mu=$ Overall mean (constant).

$\mathrm{Si}=$ Fixed effects of sex

eij $=$ Random residual error

\section{Results and Discussion}

Table 1 presents the values for the effect of sex on the least square means of haematological components in Japanese quails at six weeks. The estimates for the blood constituents of haemoglobin $(\mathrm{Hb})$, red blood count (RBC), packed cell volume (PCV), mean corpuscular haemoglobin count (MCHC), mean corpuscular haemoglobin $(\mathrm{MCH})$ and mean corpuscular volume (MCV) obtained for Japanese quails in this 
study are consistent with those reported previously by El-Deen et al. (2009); Scholtz, et al. (2009); Tuluen et al. (2011); Arora, (2011); Hassan, (2011); Tuleun et al. (2013).

Sex has significant influence on $\mathrm{Hb}, \mathrm{RBC}$ and $\mathrm{MCHC}$ with females having higher values than males while PCV, MCH and MCV show no significant sex difference. This observation is consistent with previous studies (Scholtz, 2009; Mossad and Iben, (2009); Hassan (2011) but disagrees with the study by Farahat et al.(2010) who reported no significant difference between sexes and Mihailov et al. (1999) and Abdel Fattah et al. (2001) who reported that males had significantly higher blood component values than females in Japanese quail. The differences in value (females have higher values of these constituents than males) are attributable to the fact that at this age, there are physiological changes in metabolism of the female Japanese quail due to preparation for onset of laying.

Table 2 least square means and standard error of mean for body weight and carcass components for Japanese quails at six weeks. The estimate for carcass weight, carcass yield, breast portion, thigh, back, right wing, left wing and dressing percentage for Japanese quails at six weeks in this study falls within the range reported in previous studies by Kawahara \& Satto (1976), Toelle et al. (1991), Aksit et al. (2003) and Vali et al. (2005). The significant $(\mathrm{P} \square 0.05)$ effect of sex on all carcass traits studied is in agreement with the results of Yalcin et al. (1995), Yannakopoulos et al. (1995), Toelle et al. (2000), Vali et al. (2005) and Alkan et al. (2010), but disagrees with that of Ayorinde (1994) who reported insignificant sex effect on carcass parameters. Weight of carcass components are influenced by weight at slaughter as conditioned by differences in climatic, managerial conditions of rearing, differences in genetic make-up as well as the statistical manipulation of the data used to obtain the estimates (Daikwo, 2014).

The difference in carcass weight favouring females is because studies have shown that females have higher weight of heart, liver and giblet than those in male and that heavier internal organ of female birds resulted in an increased slaughter weight and hot carcass weight (Ozcelik et al. 1998; Selim et al. 2006). In terms of breast cut, the females were significantly (P $\square 0.05)$ higher than the males which agree with Vali et al. (2005) and Alkan et al. (2010), but disagree with Aksit et al. (2003) and Genchev et al. (2005) who reported that the difference between the sexes in respect to breast percent was not significant.

Table 3 shows the genetic correlation and phenotypic correlation of body weight and blood constituents in Japanese quails at six weeks. The results of phenotypic correlation between blood constituents and body weight in this study showed that $\mathrm{Hb}$ is highly significantly $(\mathrm{P}<0.01)$ correlated with body weight at BD6 while PCV showed negative non significant correlation. MCHC is positively and significantly $(\mathrm{P}<0.05)$ correlated with BD6 and $\mathrm{Hb}$ but negatively and significantly $(\mathrm{P}<0.05)$ correlated with $\mathrm{PCV}$. For the genetic correlation, $\mathrm{Hb}$ and MCHC correlated highly significantly $(\mathrm{P}<0.01)$ with body weight six weeks. Significant $(\mathrm{P}<0.01)$ and negative correlation were found between PCV and BD6. Similar results of phenotypic and genetic correlation have been reported by Farahat et al. (2010). The blood parameters in this study are phenotypically correlated with each other and genetically with highly significant $(\mathrm{P}<0.01)$ values. Also, the high genetic and phenotypic correlation values obtained may be attributed to the pleiotropic effects and consequently performing selection in any of the traits may lead to an improvement in the other trait. Correlation among these blood parameters indicates that, estimate of one of these parameters could be used as a good indicator for the other parameters based on the high correlation values which were obtained in this study. Thrall (2004) and Elagibard and Ahmed (2011) have reported that haematological parameters can act as indicators for the state of birds health and body data can be useful aids to diagnose of diseases in birds and abnormalities due to diseases can change blood parameters (Huss et al. 2008; Elizabeth et al. 2007), it follows from the positive correlation that exists between body weight and blood constituents that selection for blood constituents can be done at early stages of life.

\section{Conclusion}

The results of the present findings indicate that body weight as a parameter for selection has positive and significant relationship with some blood parameters in Japanese quails and that the haematological parameters are influenced by sex. This can be a useful tool in developing breeding programmes in Japanese quails.

\section{References}

[1]. Abdel Fattah, M.H, El-Full E.A., Farahat, G.S, Hatba N.A. and Khalifa, M.A. (2001). Inheritance of body weight, growth rate and fitness traits in Japanese quail. Egypt. Poult. Sci.26: 1195-1215.

[2]. Aksit, M., Oguz, I., Akbas, Y., Altan, O. and Ozdogan, M. (2003). Genetic variation of feed traits and relationships to some meta production traits in Japanese quail (Coturnix coturnix japonica). Arch Geflugelkd 67(2)76-82.

[3]. Alkan, S., Karabag, K., Galic, A., Karsli, T. And Balcioglu, M.S. (2010) Determination of body weight and some carcass traits in Japanese quails (Cortunix cortunix japonica) of different lines. Kafkas Univ. Vet Fak Derg 16(2):277-280

[4]. Arora, K.L. (2010). Differences in Hemoglobin and Packed Cell Volume in Blood Collected from Different Sites in Japanese Quail (Coturnix japonica). International Journal of Poultry Science 9 (9): 828-830.

[5]. Awobajo, O.K., Skinrolabu, A.A., Mako, A.O., Igbosanu, A.O. and Olatokunbo, O.T. (2007). The mortality rate of two different breeds of broilers after brooding stage to maturity. Middle-East Journal of Scientific Research 2(1):37-42.

[6]. Ayorinde, K.L. (1994). Evaluation of the growth and carcass characteristics of the Japanese quail. Nig. J. Anim. Prod. 21(2):119126 
[7]. Baumgartner, J. (1993). Japanese Quail production, breeding and genetics. Proceedings of the $10^{\text {th }}$ International Symposium on current problems of avian genetics. Nitra. Solvakia pp. $101-103$

[8]. Daikwo, I.S. (2010). Genetic studies of Japanese quail (Cortunix cortunix japonica) in a tropical environment. Ph.D. Thesis University of Agriculture, Makurdi, Nigeria. 162pp

[9]. El Deen, M.B., Kosba, M.A. and Soliman, A.S.A. (2009). Studies of some performance and blood constituents traits in Japanese quail. Egypt. Poult. Sci. 29: 1187-1208.

[10]. Elagibard, H.A.A. and Ahmed, A.D.A.(2011). Comparative study on Haematological values of blood of indigenous chickens in sudden Asian Journal of Poultry Science, Pp.:1-5.

[11]. Elizabeth M.; Paulillo, A.C; Elizabeth, S. and Goncalves de.O. (2007). Haematological and serum chemistry values for the Ringnecked pheasant variation with sex and Age. International Journal of Poultry Science. 6(2):137-139.

[12]. Genchev, A., Mihaylova, G., Ribarski, S., Pavlov, A. And Kabakchiev, M. (2008). Meat quality and composition in Japanese quails. Trakia J. Sci. 6(4):72-82

[13]. Huss, D. G. and Poynterand Lansford, R.(2008). Japanese quail as a laboratory animal model. Lab Animal. 37:513-519

[14]. Jain N.C. (1986). Schalm's Veterinary Haematology 4th ed. WB Saunders and Company, Philadelphia $1221 \mathrm{pp}$.

[15]. Kawahara, T. and Satto, K. (1976). Genetic parameters of organ and body weight in the Japanese quails. Poult. Sci.55:1247-1252

[16]. Kendall, H.W. and Pimentel, D. (1994). Constraints on the expansion of the global food supply. Ambio 23:198-205

[17]. Kul, S. And Seker, I. (2004). Phenotypic correlations between some external and internal egg quality traits in the Japanese quail (Cortunix cortunix japonica). International Journal of Poultry Science 3(6):400-405

[18]. Minvielle, F., (2004). The future of Japanese quail for research and production. World Poult. Sci. J. 60, 500-507.

[19]. Mosaad, G.M.M. and Iben, C. (2009). Effect of dietary energy and protein levels on growth performance and carcass yield and some blood constituents of Japanese quails (Cortunix cortunix japonica). Die Bodenkultur 60(4):39-46

[20]. Olomu, J.M. (1995). Monogastrics Animal Nutrition - Principles and Practice. Jachem Publ. P:111-148

[21]. Onu P. N., Madubuike F. N., Onu D.O. and Ekenyem B. U. (2011). Performance and economic analysis of broiler Starter chicks fed enzyme supplemented sheep Manure-based diets. ARPN Journal of Agricultural and Biological Science. Pp 14 - 19

[22]. Oyewale, J.O. (1992). Changes in osmotic resistanceof erythrocytes of cattle, pigs, rats and rabbits during variations in temperature and $\mathrm{pH}$. J Vet Med 39:98-104

[23]. Ozcelik, M., Poyraz, O., Akinci, Z., (1998). The effect of sex on slaughter and carcass characteristics in quails, Firat University J. Institute of Health Sci., 12(2): 133-39.

[24]. Scholtz, N., Halle, I. Flachowsky, G. and Sauerwein, H. (2009). Serum chemistry reference values in adult Japanese quail (Cortunix cortunix japonica) including sex-related differences. Poultry Science 88:1186-1190.

[25]. Selim, K., Ibarhim, S., Ozge, Y., 2006. Effect of separate and mixed rearing according to sex on tattering performance and carcass characteristics in Japanese quails. (Coturnix coturnix Japonica). Arch Tierz., Dummerstort. 49(6), 607-614.

[26]. SPSS (2011). User's Guide: Statistics. IBM Version 20. SPSS Inc., Chicago, IL, USA.

[27]. Thrall, M.A. (2004). Veterinary Haematology and Clinical Chemistry. Lippincott and Wilkins, Philadelphia, Pp.: 518.

[28]. Toelle, V.D., Havenstein,G.B., Nestor, K. and Harvey, W.R. (1991). Genetic and phenotypic relationships in Japanese quails. Body weight, carcass and organ measurements. Poult. Sci.4:1679-1688

[29]. Tuleun C. D., Adenkola A.Y. and Yenle, F.G. (2013). Performance and Erythrocyte osmotic membrane stability of laying Japanese quails (Cortunix cortunix japonica) fed varying dietary protein levels in a hot- humid tropics. Agric. Biol. J.N. Am.,4(1):6-13

[30]. Vali, N. (2008). The Japanese quail: a review. International Journal of Poultry Science 7(9):925-931

[31]. Vali, N., Edriss, M.A. and Moshtaghi, H. (2006). Comparison of egg weight between two quail strains. International Journal of Poultry Science 4(5):398-400.

[32]. Vali, N., Edriss, M.A. and Rahmani, H.R. (2005). Genetic parameters of body and some carcass traits in two quail strains. International Journal of Poultry Science 4(5):296-300.

[33]. Yalcin, S., Oguz, I. And Otles, S. (1995). Carcass characteristics of quail Coturnix coturnix japonica slaughtered at different ages. Br. Poult. Sci. J. 36:393-399.

[34]. Yannakopoulos, A. L., Christaki, F. and Paneri, P.F. (1995). Effect of age and carcass composition on the onset of sexual maturity in quail under normal feeding regimens. Br. Poult. Sci. 36: 771-777.

Table 1: Effect of sex on least square means of blood constituents of Japanese quails at six weeks

\begin{tabular}{|c|c|c|c|c|c|c|c|}
\hline Parameter & Sex & No & Means \pm SEM & Range & Min & Max & $\mathrm{CV}(\%)$ \\
\hline $\mathrm{HB}$ & $\begin{array}{l}\mathrm{M} \\
\mathrm{F}\end{array}$ & $\begin{array}{l}25 \\
32\end{array}$ & $\begin{array}{l}12.36+0.15= \\
13.20+0.15=\end{array}$ & $\begin{array}{l}2.80 \\
3.30\end{array}$ & $\begin{array}{l}11.10 \\
11.30\end{array}$ & $\begin{array}{l}13.90 \\
14.60\end{array}$ & $\begin{array}{l}6.11 \\
6.53\end{array}$ \\
\hline $\mathrm{RBC}$ & $\begin{array}{l}\mathrm{M} \\
\mathrm{F}\end{array}$ & $\begin{array}{l}25 \\
32\end{array}$ & $\begin{array}{l}2.50+0.03= \\
2.59+0.03=\end{array}$ & $\begin{array}{l}0.50 \\
0.50\end{array}$ & $\begin{array}{l}2.20 \\
2.30\end{array}$ & $\begin{array}{l}2.70 \\
2.80\end{array}$ & $\begin{array}{l}5.42 \\
5.49\end{array}$ \\
\hline $\mathrm{PCV}$ & $\begin{array}{l}\mathrm{M} \\
\mathrm{F}\end{array}$ & $\begin{array}{l}25 \\
32\end{array}$ & $\begin{array}{l}37.80+0.26^{\mathrm{m}} \\
38.22+0.33^{\mathrm{m}}\end{array}$ & $\begin{array}{l}4.00 \\
6.00\end{array}$ & $\begin{array}{l}36.00 \\
35.00\end{array}$ & $\begin{array}{l}40.00 \\
41.00\end{array}$ & $\begin{array}{l}3.42 \\
4.83\end{array}$ \\
\hline $\mathrm{MCHC}$ & $\begin{array}{l}\mathrm{M} \\
\mathrm{F}\end{array}$ & $\begin{array}{l}25 \\
32\end{array}$ & $\begin{array}{l}32.78+0.91= \\
34.61+0.42=\end{array}$ & $\begin{array}{l}6.40 \\
11.01\end{array}$ & $\begin{array}{l}9.07 \\
27.56\end{array}$ & $\begin{array}{l}28.50 \\
38.57\end{array}$ & $\begin{array}{l}7.57 \\
7.33\end{array}$ \\
\hline $\mathrm{MCH}$ & $\begin{array}{l}\mathrm{M} \\
\mathrm{F}\end{array}$ & $\begin{array}{l}25 \\
32\end{array}$ & $\begin{array}{l}49.84+0.91^{=} \\
51.14+0.91^{=}\end{array}$ & $\begin{array}{l}20.96 \\
17.22\end{array}$ & $\begin{array}{l}42.22 \\
43.21\end{array}$ & $\begin{array}{l}63.18 \\
60.43\end{array}$ & $\begin{array}{l}9.10 \\
7.80\end{array}$ \\
\hline $\mathrm{MCV}$ & $\begin{array}{l}M \\
F\end{array}$ & $\begin{array}{l}25 \\
32\end{array}$ & $\begin{array}{l}151.65+1.71^{m} \\
148.21+2.05^{m}\end{array}$ & $\begin{array}{l}39.39 \\
40.00\end{array}$ & $\begin{array}{l}133.33 \\
128.57\end{array}$ & $\begin{array}{l}172.73 \\
169.57\end{array}$ & $\begin{array}{l}5.66 \\
7.81\end{array}$ \\
\hline
\end{tabular}

$\mathrm{a}, \mathrm{b}=$ Means within sex-subgroup with different superscript are significantly different $(\mathrm{P} \square 0.05)$, ns $=$ not significant, $\mathrm{N}=$ No of observations, Min= Minimum value, Max= Maximum value, $\mathrm{SEM}=$ standard error of mean, $\mathrm{Hb}=$ Haemoglobin, $\mathrm{RBC}=$ Red blood count, $\mathrm{PCV}=$ Packed cell volume, $\mathrm{MCHC}=\mathrm{Mean}$ corpuscular 
Effect of sex on carcass characteristics and correlation of body weight and blood components....

haemoglobin count, $\mathrm{MCH}=$ Mean corpuscular haemoglobin, $\mathrm{MCV}=$ Mean corpuscular volume, $\mathrm{CV}=$ Coefficient of variation.

Table 2: Least square Means \pm SEM of mean for body weight and carcass components for Japanese quails at six weeks

\begin{tabular}{|c|c|c|c|c|c|c|}
\hline Parameter & Sex & $\mathrm{N}$ & Min & $\operatorname{Max}$ & Mean & SD \\
\hline$\overline{\mathrm{BD}(\mathrm{g})}$ & $\begin{array}{l}\mathrm{M} \\
\mathrm{F} \\
\mathrm{C}\end{array}$ & $\begin{array}{l}25 \\
32 \\
57\end{array}$ & $\begin{array}{l}120.56 \\
121.70 \\
120.80\end{array}$ & $\begin{array}{l}141.20 \\
143.60 \\
143.60\end{array}$ & $\begin{array}{l}129.56 \pm 1.25 \\
136.82 \pm 1.06 \\
133.63 \pm 0.93\end{array}$ & $\begin{array}{l}6.25 \\
6.00 \\
7.06\end{array}$ \\
\hline $\mathrm{CW}(\mathrm{g})$ & $\begin{array}{l}\mathrm{M} \\
\mathrm{F} \\
\mathrm{C}\end{array}$ & $\begin{array}{l}25 \\
32 \\
57\end{array}$ & $\begin{array}{l}96.60 \\
103.20 \\
96.60\end{array}$ & $\begin{array}{l}124.40 \\
134.80 \\
134.80\end{array}$ & $\begin{array}{l}114.58 \pm 1.48 \\
120.34 \pm 1.44 \\
117.81 \mp 1.09\end{array}$ & $\begin{array}{l}7.38 \\
8.13 \\
8.27\end{array}$ \\
\hline $\mathrm{CY}(\mathrm{g})$ & $\begin{array}{l}\mathrm{M} \\
\mathrm{F} \\
\mathrm{C}\end{array}$ & $\begin{array}{l}25 \\
32 \\
57\end{array}$ & $\begin{array}{l}83.60 \\
90.20 \\
83.60\end{array}$ & $\begin{array}{l}110.40 \\
121.80 \\
121.80\end{array}$ & $\begin{array}{l}101.43 \pm 1.44 \\
107.40 \pm 1.39 \\
104.79+1.07\end{array}$ & $\begin{array}{l}7.20 \\
7.89 \\
8.10\end{array}$ \\
\hline $\mathrm{BR}(\mathrm{g})$ & $\begin{array}{l}\mathrm{M} \\
\mathrm{F} \\
\mathrm{C}\end{array}$ & $\begin{array}{l}25 \\
32 \\
57\end{array}$ & $\begin{array}{l}29.50 \\
33.40 \\
29.50\end{array}$ & $\begin{array}{l}45.40 \\
49.00 \\
49.00\end{array}$ & $\begin{array}{l}40.66+0.80 \\
42.83 \pm 0.73 \\
41.88+0.55\end{array}$ & $\begin{array}{l}4.01 \\
4.11 \\
4.18\end{array}$ \\
\hline $\mathrm{TH}(\mathrm{g})$ & $\begin{array}{l}\mathrm{M} \\
\mathrm{F} \\
\mathrm{C}\end{array}$ & $\begin{array}{l}25 \\
32 \\
57\end{array}$ & $\begin{array}{l}21.90 \\
23.10 \\
21.90\end{array}$ & $\begin{array}{l}27.60 \\
29.60 \\
29.60\end{array}$ & $\begin{array}{l}24.91+1.49 \\
26.35+0.31 \\
25.72+0.23\end{array}$ & $\begin{array}{l}1.49 \\
1.74 \\
1.77\end{array}$ \\
\hline $\mathrm{BK}(\mathrm{g})$ & $\begin{array}{l}\text { M } \\
\text { F } \\
\text { C }\end{array}$ & $\begin{array}{l}25 \\
32 \\
57\end{array}$ & $\begin{array}{l}22.70 \\
23.90 \\
22.70\end{array}$ & $\begin{array}{l}28.60 \\
30.70 \\
30.70\end{array}$ & $\begin{array}{l}25.84+0.31 \\
27.33+0.32 \\
26.68+0.24\end{array}$ & $\begin{array}{l}1.55 \\
0.37 \\
1.85\end{array}$ \\
\hline$R T$ (g) & $\begin{array}{l}\mathrm{M} \\
\mathrm{F} \\
\mathrm{C}\end{array}$ & $\begin{array}{l}25 \\
32 \\
57\end{array}$ & $\begin{array}{l}4.70 \\
4.90 \\
4.70\end{array}$ & $\begin{array}{l}5.90 \\
6.30 \\
6.30\end{array}$ & $\begin{array}{l}5.33+0.06 \\
5.64 \pm 0.06 \\
5.50+0.05\end{array}$ & $\begin{array}{l}0.32 \\
0.37 \\
0.37\end{array}$ \\
\hline $\operatorname{LT}(\mathrm{g})$ & $\begin{array}{l}\mathrm{M} \\
\mathrm{F} \\
\mathrm{C}\end{array}$ & $\begin{array}{l}25 \\
32 \\
57\end{array}$ & $\begin{array}{l}4.60 \\
4.90 \\
4.60\end{array}$ & $\begin{array}{l}5.80 \\
6.20 \\
6.20\end{array}$ & $\begin{array}{l}5.24+0.06 \\
5.54+0.06 \\
5.41+0.05\end{array}$ & $\begin{array}{l}0.32 \\
0.36 \\
0.37\end{array}$ \\
\hline $\mathrm{DP}(\%)$ & $\begin{array}{l}\mathrm{M} \\
\mathrm{F} \\
\mathrm{C}\end{array}$ & $\begin{array}{l}25 \\
32 \\
57\end{array}$ & $\begin{array}{l}67.10 \\
72.70 \\
67.10 \\
\end{array}$ & $\begin{array}{l}81.90 \\
86.40 \\
86.40 \\
\end{array}$ & $\begin{array}{l}76.84+0.71 \\
79.63+0.60 \\
78.40+0.49 \\
\end{array}$ & $\begin{array}{l}3.56 \\
3.37 \\
3.70 \\
\end{array}$ \\
\hline
\end{tabular}

$\mathrm{BD}=$ bodyweight, $\mathrm{N}=$ No of observations, $\mathrm{Min}=$ Minimum value, Max= Maximum value, $\mathrm{SEM}=$ Standard error of mean, $\mathrm{CW}=$ Carcass weight, $\mathrm{CY}=$ Carcass yield, $\mathrm{BR}=$ Breast portion, $\mathrm{TH}=$ Thigh portion, $\mathrm{BK}=\mathrm{Back}$ portion, $\mathrm{RT}=$ Right wing portion, $\mathrm{LT}=$ Left wing portion, $\mathrm{DP}=$ Dressing percentage, $\mathrm{g}=$ grams, $\mathrm{SD}=\mathrm{Standard}$ deviation., $\mathrm{M}=$ male, $\mathrm{F}=$ female, $\mathrm{C}=$ combined sexes

Table 3: Genetic correlation (above diagonal) and phenotypic correlation (below diagonal) of Body Weight and Blood Constituents in Japanese quails at six weeks.

\begin{tabular}{llllllll}
\hline & BD6 & HB & RBC & PCV & MCHC & MCH & MCV \\
\hline BD6 & & $0.775^{* *}$ & $0.659^{* *}$ & $0.649^{* *}$ & $0.839^{* *}$ & -0.367 & $-0.724^{*}$ \\
HB & $0.300^{*}$ & & 0.287 & -0.440 & $0.856^{* *}$ & 0.178 & 0.494 \\
RBC & 0.134 & 0.190 & & $-0.925^{* *}$ & $0.773^{* *}$ & $-0.866^{* *}$ & $-0.999^{* *}$ \\
PCV & -0.059 & 0.192 & 0.022 & & $0.825^{* *}$ & $0.806^{* *}$ & $0.995^{* *}$ \\
MCHC & $0.314^{*}$ & $0.834^{* *}$ & 0.172 & $-0.379^{*}$ & & -0.355 & $-0.892^{* *}$ \\
MCH & 0.147 & $0.698^{* *}$ & $-0.549^{* *}$ & 0.135 & $0.577^{* *}$ & & $0.920^{* *}$ \\
MCV & -0.162 & -0.043 & $-0.808^{* *}$ & $0.563^{*}$ & $-0.361^{* *}$ & $0.539 * *$ \\
\hline
\end{tabular}

$\mathrm{Hb}=$ Haemoglobin, $\mathrm{RBC}=\mathrm{Red}$ blood count, $\mathrm{PCV}=$ Packed cell volume, $\mathrm{MCHC}=\mathrm{Mean}$ corpuscular haemoglobin concentration, $\mathrm{MCH}=$ Mean corpuscular haemoglobin, $\mathrm{MCV}=$ Mean corpuscular volume, $*=\mathrm{P} \square 0.05, * *=\mathrm{P} \square 0.01$ 